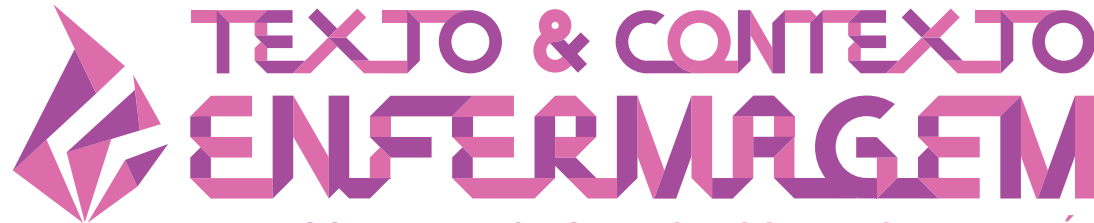

TEXT \& CONTEXT NURSING TEXTO \& CONTEXTO ENFERMERÍA

\section{THE MORAL VALUES OF NURSING UNDERGRADUATION: PERCEPTION OF TEACHERS AND STUDENTS}

\section{Lumaira Maria Nascimento Silva da Rocha Marques ${ }^{1}$ (i) Carlos Dimas Ribeiro ${ }^{1}$}

'Universidade Federal Fluminense, Programa de Pós-Graduação em Bioética, Ética Aplicada e Saúde Coletiva. Niterói, Rio de Janeiro, Brasil.

\begin{abstract}
Objective: to compare the moral values that nursing teachers and students consider important for vocational training with those they believe are promoted throughout undergraduate study.

Method: a qualitative research; an ethnographic study conducted at a public nursing school in the state of Rio de Janeiro, in 2018, involving 40 interviews with teachers and students and a participant observation phase.

Results: the moral values that teachers and students consider important for vocational training, as well as those that are promoted, converge on prudence, respect, responsibility, and empathy. It is noteworthy that the knowledge was much cited by the respondents and this article interpreted it as prudence. However, in relation to the values promoted during undergraduation, students warn that these are stimulated when referring to the binomial student-user of health, because they do not feel to the same intensity the presence of these moral values in the teacher-student relationship.

Conclusion: a powerful strategy for teaching about moral values is to promote the care of their own students, teachers and staff. In this way, mismatches are avoided between what is said and what is done by experiencing values such as prudence, respect, responsibility and empathy within interpersonal relationships and in the daily life of the school.
\end{abstract}

DESCRIPTORS: Nursing education. Ethics. Deontological ethics. Ethics, nursing. Moral. 


\section{OS VALORES MORAIS DA GRADUAÇÃO DE ENFERMAGEM: PERCEPÇÃO DE PROFESSORES E ESTUDANTES}

\section{RESUMO}

Objetivo: comparar os valores morais que professores e estudantes de enfermagem consideram importantes para a formação profissional com aqueles que eles acreditam que são promovidos ao longo da graduação. Método: pesquisa qualitativa; um estudo etnográfico realizado em uma faculdade pública de enfermagem do estado do Rio de Janeiro, em 2018, envolvendo 40 entrevistas com professores e estudantes e uma fase de observação participante.

Resultados: os valores morais que os professores e estudantes avaliam ser importantes para a formação profissional, bem como aqueles que são promovidos, convergem para a prudência, o respeito, a responsabilidade e a empatia. Vale destacar que o conhecimento foi muito citado pelos entrevistados e, este artigo, interpretou-o como prudência. Todavia, em relação aos valores promovidos ao longo da graduação, os estudantes alertam que estes são estimulados quando referem-se ao binômio estudante-usuário de saúde, pois não sentem na mesma intensidade a presença desses valores morais na relação professor-estudante.

Conclusão: uma potente estratégia para ensinar sobre os valores morais é promover o cuidado dos seus próprios estudantes, professores e funcionários. Dessa maneira, evitam-se desencontros entre o que se diz e o que se faz ao vivenciar os valores como a prudência, o respeito, a responsabilidade e a empatia dentro das relações interpessoais e no cotidiano da faculdade.

DESCRITORES: Educação em enfermagem. Ética. Ética deontológica. Ética em enfermagem. Moral.

\section{LOS VALORES MORALES DE LA CARRERA DE GRADO DE ENFERMERÍA: LA PERCEPCIÓN DE DOCENTES Y ESTUDIANTES}

\section{RESUMEN}

Objetivo: comparar los valores morales que los profesores y estudiantes de enfermería consideran importantes para la formación profesional con los que creen que se promueven a lo largo de la carrera de grado.

Método: investigación cualitativa; un estudio etnográfico realizado en el año 2018 en una facultad pública de enfermería del estado de Río de Janeiro, por medio de 40 entrevistas con profesores y estudiantes y una fase de observación de los participantes.

Resultados: los valores morales que los profesores y estudiantes evalúan como importantes para la formación profesional, al igual como los que se promueven, convergen en la prudencia, el respeto, la responsabilidad y la empatía. Cabe destacar que el conocimiento fue muy citado por los entrevistados y, en este artículo, se lo interpretó como prudencia. Pese a ello, en relación con los valores promovidos a lo largo de la carrera de grado, los estudiantes manifiestan que se los fomenta cuando se refieren al binomio estudiante-usuario de servicios de salud, puesto que no sienten con la misma intensidad la presencia de estos valores en la relación profesor-estudiante.

Conclusión: estamos frente a una poderosa estrategia para enseñar sobre los valores morales y promover el cuidado de sus propios estudiantes, profesores y personal administrativo. De esta manera, se evitan desencuentros entre lo que se dice y lo que se hace al respetar valores como la prudencia, el respeto, la responsabilidad y la empatía dentro de las relaciones interpersonales y en la vida cotidiana de la facultad.

DESCRIPTORES: Educación en enfermería. Ética. Ética deontológica. Ética en enfermería. Moral. 


\section{INTRODUCTION}

The purpose of education, from primary to higher, is to educate people who know, in addition to governing their own lives, to live in society. In other words, education is not only about realizing an individual good - vocational training, for example -, but also about forming people capable of aiming for a collective good. Therefore, education must be responsible for promoting democratic values. This requires an education based on moral values that leads to the ethical development of the subject. ${ }^{1-2}$

Moral education in Brazilian universities is often associated with the teaching of the code of ethics, through the mere inclusion of deontological disciplines, favoring the knowledge of professional laws, but generally without the necessary reflections to promote moral autonomy. Nevertheless, the ethical dimension of higher education is not restricted to deontological issues. ${ }^{3}$

Regrettably, in Brazilian universities we still notice the valorization of technical and scientific knowledge, adjusting the professional formation according to the logic of the labor market, which causes a marginalization of moral discussions. ${ }^{4}$ Thus, nursing, even having as a principle of profession the care of others from the perspective of integrality, often leaves its actions below expectations. In view of this, the Ministry of Education has instituted National Curriculum Guidelines (NCGs) ${ }^{5}$ defining the competences and skills expected for nursing professionals, with the purpose of proposing curriculum changes that bring the profile of the egress to the principles and guidelines of the Unified Health System (Sistema Único de Saúde, SUS). One of the changes focuses on training a humanist, critical and reflective professional; this requires an investment in teaching the ethical dimension.

Considering the strong link between nursing and ethics, due to the care relationships inherent to the profession, moral education in undergraduate education permeates the most diverse learning scenarios, whether planned or not. It is up to teachers to become aware of the greatness of the social character of their role, not only by training professionals who do their jobs well, but also by training citizens who do good. ${ }^{4}$

Moral education presupposes a constructive task, given that it is not imposed by values, not only from the process of socialization or moral development, nor is it reduced to the acquisition of virtuous habits. Puig ${ }^{6}$ believes that these theories in isolation are incomplete, that they must be thought of in a complementary way; therefore, it considers moral education as a process of building moral personality. According to the author, building up a moral personality depends on the experience that the environment is capable of providing, the use of the instruments of moral conscience and must have a guide of values that assists in the moral direction of action.

In order for teachers to facilitate the process of building the moral personality of their students, they should, along with the institution, have clear moral values that they intend to promote. What would be the desired moral values for nursing education? What is the professional profile you want to qualify? Are the moral values that we think are important for formation the same we can promote in our teaching practices? These were some questions that drove this research and, looking for answers in the literature, we observed a lack of investigations involving this theme. Moral values are considered to be implicitly and unplanned in the nursing curriculum, which creates room for dissonance between what is said and what is practiced.

Thus, the aim of this paper was to compare the moral values that nursing teachers and students consider important for professional education with those they believe are promoted throughout undergraduate education. 


\section{METHOD}

This is a qualitative research. An ethnography was performed, that is, an immersion with direct and prolonged contact with the research object, conducted with a reflexive sensitivity and composed by looking, hearing and writing. ${ }^{7}$ The look was constituted through participant observation, listening with individual interviews to teachers and nursing students and writing was built from the field diary records. Data was collected in 2018.

The invitation to participate in the research was made to all the school teachers in person during departmental meetings. The invitation to all the students was held in the classroom, with prior authorization from the subject teachers. The research participants were those who expressed interest, respecting the following inclusion criteria: students enrolled from the first to the fourth year of undergraduate nursing and who attended all periods prior to the current one in the researched institution; and teachers with an effective contract who taught from the first to the fourth year of nursing, with a workload of twenty hours or more and who had been in the institution for more than four years.

The study involved 40 research participants, of which 20 were teachers and 20 were students. Among the teachers, there were 17 women and 3 men, with a mean working time at the institution of 16.3 years and the following distribution: four teachers taught in the first year of graduation, six in the second year, six in the third year and four in the fourth year. There were at least two teachers from each scholarship period. Most teachers (18) were nurses.

The student population consisted of 17 women and 3 men, aged 18 to 29 years old, with predominance in the range of 20 to 23 years old. Five students were in first year, four were in second year, seven were in third year and four were in the last year. One of them took part in the academic center.

Participant observation occurred in the subjects of the teachers who participated in the interviews, whether in theoretical or practical activities, and also in the university's living spaces, such as corridors, waiting rooms and coordination. Some examples for observed points were the following: if there was respect and dialog between teachers and students; if the teacher problematized real situations to discuss moral values and if there were spaces that provided the experience of moral values.

The interviews were recorded without the participants' identification and, after transcription, the audios were erased so that their voice could not be identified, keeping only the transcriptions, identified with the abbreviations DO1, DO2 (...), for the interviews with the teachers, and DI1, DI2 (...), for the interviews with the students.

The guiding questions of the interviews were which moral values the participants considered important for the education of the nurse and which they believed were promoted throughout the course. It was also asked what the profile of the nursing professional they envisioned was. It is worth pointing out that at times, both students and teachers have found it difficult to answer some questions. As a way of mitigating the situation, certain words and/or phrases have been reformulated with simpler language.

Data was processed through thematic content analysis, according to Minayo, ${ }^{8}$ following the stages ahead: 1) pre-analysis of the results, which determines a fluctuating reading and exhaustive appropriation of the achieved data; 2) exploration of the material, which consists of finding the categories that express the content of the speeches and records of the field diary, then classifying and aggregating the data; and 3) treatment and interpretation of the obtained data, correlating with theoretical references.

The research was conducted according to the ethical standards required by Resolution No.466, December $12^{\text {th }}, 2012$, of the National Health Council. 


\section{RESULTS}

Before going into the analysis of the interviewees' statements, it is important to clarify how values are constructed by individuals, to understand why a human being appropriates a certain value and not others. According to Piaget, ${ }^{9}$ the values are constructed according to the affective exchanges that the subject makes with the world, that is, they value what they value from their interaction, whether moral or not. All human beings build non-moral values because it is inherent in human nature to value things, people or situations. However, the construction of moral value depends on the quality of interactions, so its process is not natural and simple. Here comes the role of value education in the establishment of strategies that aim to promote socially desirable moral values in school activities. ${ }^{10}$

The values emerging from the statements of teachers and students are those that were somehow constituted as significant throughout their lives. It was observed that not all values cited were moral, even when the question led specifically to this field.

\section{The important moral values}

When teachers were asked about which moral values should be worked in undergraduate nursing, they focused on some, such as: empathy, respect, responsibility, having scientific knowledge, being updated, being ethical, having compassion, solidarity, being true, honest, having autonomy and sensitivity. A sample of the mention of moral values can be seen in the example below:

Empathy for me is the main thing. You put yourself in the other's shoes so that you have a sense of the care you want to give, because without empathy, without dedication... but it is not enough to have empathy without dedication to deepen the knowledge (DO19).

Students, in a very similar way, pointed empathy, respect, responsibility, scientific knowledge, professional ethics, honesty, loyalty and sensitivity as important moral values for their formation. The quote below is also illustrative:

I think the main thing is respect, because we need the teacher's respect towards us, the people with the nurses with whom we work in the practice [...] respect for our profession; respect for the coordination. So, I think it's this that guides our care and our attention (DI17).

During participant observation, it was possible to experience various situations that covered moral values. The inaugural class and the magna class, which are conferences to begin the schooling year, featured a hopeful discourse on citizenship education, in which values such as love, empathy, sensitivity, responsibility, solidarity, freedom, respect and equality. In specific subjects, in addition to the values mentioned, the speeches alluded to values such as trust, honesty, sympathy, patience, bond, dialog, justice and consistency with the professional code. Walking the university corridors is also inevitably living with diversity. Heterogeneity invites a more harmonious coexistence among them through posters on black empowerment, against homophobia; there are poems, self-help messages and invitations to prayer groups, a rich and vast moral pluralism.

Another way to get answers about the moral values that the research participants think are important for undergraduate students was to ask about their professional profile as a good professional. This question refers to moral values because, to answer it, we select the characteristics we most admire, revealing whether or not our priorities have moral content. Regarding the answers, the most evoked value was knowledge:

Reflective, critical, articulates theory and practice, empathic, human, scientifically aware, and able to work in teams (DO1).

First, having scientific knowledge, because there should be a lot of research, a lot of wisdom, a lot of study. Also knowing how to deal with others' problems, being creative, having empathy, being polite to the patient (DI5). 


\section{The promoted moral values}

When asked what moral values they can promote within undergraduate nursing, teachers unanimously recognize respect, empathy, responsibility, humanization, honesty, dialog, autonomy and truth.

Following is a teacher's speech about his moral values: I don't work all [the moral values] in all classes, but in my classes I always work some, such as dialog, knowledge sharing, horizontality in the professional-user relationship. And I work beyond theoretical discourse, I work on the example; it is part of my posture as a teacher to be punctual, for example (DO4).

Regarding the moral values that students consider to be promoted in undergraduate nursing, they are more optimistic than teachers, because they identify more circumstances in which education in values occurs. Most claim that the moral values cited have been worked on along the course, a fact represented in the quote: I think empathy was greatly encouraged. They teach me to position myself, to put myself in the patient's shoes, to see if I would like that treatment for myself or my family (DI1).

However, some students also warn that the encouragement of moral values does not always go beyond the student-health user relationship, as stated by student D19:

I think hypocrisy is pretty high, because while we hear that we have to be empathic, we don't see that from some professionals who instruct us, you know? (DI19).

During participant observation, situations were experienced focusing on moral values. For example, in practical activities at a high-school, a group of nursing students worked on the prevention of bullying with young people and proposed a dynamic activity in order to raise the self-esteem of the individuals and promote the valorization of others. Each high school student would leave a motivational note or a compliment in a box without directing it to a specific recipient and pick up another note. The activity included speeches of peace, cooperation, solidarity and empathy. Another case observed was in a hospital setting, where I noticed a student apologizing to the teacher for demonstrating that she was thrilled with the patient's case. The teacher welcomed their anguish and said: "I am glad you get emotional, it's a sign of empathy."

\section{DISCUSSION}

Due to the extensive list of moral values cited in the research, and in view of an efficient discussion of information, focus will be given to those most highlighted by teachers and students: prudence, respect, responsibility and empathy. It is not that the other submitted values will not be pointed out in this article, since the conceptual boundaries among them are not rigid, thus allowing them to intertwine during the discussion. The choice of these four values is to be able to deepen the analysis without falling into the superficiality of the attempt to explain them all.

It is noteworthy that the knowledge was much cited by the respondents and this article interpreted it as prudence. Scientific knowledge was referred to in many lines as a moral value, which was surprising at first since it is not among the classical virtues such as humility, generosity, or courage. ${ }^{11}$ For this reason, it deserves highlighting in this discussion.

The place of speech from which the emphasis on scientific knowledge as a moral value emerged is the university, a space recognized as the cradle of science; consequently, their exaltation in speech becomes inevitable. However, knowledge, understood as information, has no moral value in itself, as it alone does not help the individual to improve morally as a person. On the contrary, knowledge can even be used for perverse uses, as happened in World War II, such as the hypothermia tests carried out on human subjects by Nazi doctors. ${ }^{12}$ Therefore, thinking so, it would be a mistake to frame it as a moral value. At the same time, we can see it as a constitutive element of intellectual virtues, a fact that would bring it closer to the moral sphere. 
Aristotle ${ }^{11}$ classifies virtues into two types: moral virtues and intellectual virtues. The first are those that enable men to perform noble deeds, such as generosity; intellectual virtues are those that extend our knowledge, such as wisdom, understanding and prudence. The latter acts as a bridge between moral virtues and intellectual virtues, since it enables man to make the right choices about the right measure of virtues. Thus moral virtues cannot exist without intellectual virtues, especially prudence. $^{13}$

In view of this, the valuation of scientific knowledge by the research participants would add relevance to the moral formation of students, provided that this value was associated with intellectual virtues, especially prudence. That is, it would be advisable to focus on the quality of content, encouraging understanding, insight into facts and ethical decision-making rather than prioritizing the amount of submitted information.

Observing the curriculum of the researched institution, it is noted that the amount of content is privileged, a fact that could be proven in person in classes of some subjects. For example, one of them had a workload of 15 hours, and the teacher worked on 17 different topics, including abortion and euthanasia, which highlights the lack of reflection in addressing controversial topics.

Another situation that proves the rooting of the content profile occurred during practical hospital activities. It was observed that the students spent five days in each sector of the hospital. The teacher explained that both the teaching staff and the students themselves prefer to spend a few days in many wards than to spend more days in one ward, because they have the opportunity to know more clinical cases. However, many points of formation are deficient with this justification:

1. The few days of internship in the same place do not favor the formation of bonds, either between student and patient, or between student and health team. Just as people only learn to perform a bandage by practicing, the also only learn to build bonds by living in environments that favor it.

2. It also does not provide a good clinical follow-up of health users. It was often observed that the students engaged in the planning and implementation of the care plan, so that the next day they would go to another sector, interrupting the continuation of care systematization and impairing the formation of responsibility for their prescriptions, after all, no longer are there to evaluate them.

3. The fact that they take care of users with different clinical cases (quantity) every day does not allow students to have time to conduct deeper studies on each situation (quality). Nor does it make it possible to promote reflection in and about action as enhancers of the teaching of integrality. ${ }^{14}$

4. The teacher, with these few days, shows difficulties to assess the student's evolution, which limits the construction of a formative assessment.

Having clarified the relationship between knowledge and prudence, the following will be presented the analysis of the other moral values cited by the research participants: respect, responsibility and empathy.

Respect, according to Sennett, ${ }^{15}$ comprehends how the individual views and treats the other; as a result, it is a relational aspect. It is the ability to communicate with others and to be involved in the world, including those most distant. Kant, ${ }^{16}$ recognizing the value of the dignity of the human person, in his categorical imperative that every individual should be regarded as an end in itself, it also supports the defense of mutual respect, since not instrumentalizing individuals is recognizing that each deserves respect. Mutual respect must transcend relationships with those closest and embrace the most vulnerable. 
Respect for the health care user is always among the competencies a student must ensure during the internship, but is not always explicitly and expressly required in the assessment formats. It is the dreaded item that assesses students' attitudes, which, since they do not understand the importance of valuing them in academic activities, often end up making them invisible, on the grounds that they refer to the "subjective" and "countless" world of an evaluation. ${ }^{4}$ For this reason, further discussion is needed on formative and procedural assessments that can go beyond memorization and technical skills.

The notion of responsibility intertwines with the concept of respect insofar as it is also based on the other. The university evokes the teaching of professional responsibility by moderating the relationship between nurses and health users, through the profession's code of ethics, and requiring nurses to exercise their office with competence, commitment, resoluteness, and dignity. ${ }^{5}$

Deontology, professional legislation and the exercise of the profession are disciplines of the researched institution, which demonstrates that the teaching of professional responsibility is among its educational priorities. Knowledge of the law is important for the formation of moral personality, helping to compose the self-regulation of the individual. Considering all the conflicts of values existing in daily nursing, professional responsibility is directly related to decision making. Therefore, responsibility cannot be restricted to knowledge and obedience to the rules, since moral dilemmas are not solved solely on the basis of the laws.

The lack of reflections on controversial topics in an educational institution can be explained by the lack of the bioethical subject in the curriculum matrix. This does not mean that the university does not work on bioethics issues; however, differentiating the bioethics discipline from others with related themes is necessary to create and strengthen spaces that allow discussion and reflection on decision making in the face of moral conflicts. ${ }^{17}$

Accountability is also encouraged by inserting students into the professional practice from the beginning of graduation as directed by the NCGs. ${ }^{5}$ These experiences provide nursing care, which requires some degree of intervention, encouraging responsibility for the health of those users.

Respect and responsibility set the stage for empathy. Empathy is defined as the ability to put oneself in the other's place and, through this process, can generate appropriate affective reactions towards the other. ${ }^{18}$ The development of empathy is not only advocated for the training of nurses, who will focus on the care of the other, is desired for the construction of the moral personality of all individuals in the society.

Teachers should keep in mind that developing pedagogical practices that enable empathy to flourish is to align with the educational ends: to train a citizen committed to the community ${ }^{19}$ and with a better world. And the individual really commits himself only to overcoming the emerging inequalities of society if, during the formative process, he is encouraged to develop moral sensitivity and, consequently, empathy. Empathy is the engine of moral action, and it does not act without respect and responsibility. ${ }^{18}$

Inserting students in realities where there is social contrast enhances the encouragement of empathy, as well as fostering values oriented towards citizenship and solidarity, advocated by the NCGs. ${ }^{5}$ This experience ensures that nursing students learn to live, as it provides activities that encompass knowledge, know-how and knowing how to live together, important attributes for the solid construction of moral personality and indispensable for the formation of nurses. ${ }^{5}$

Empathy is a socially learned skill essential for the construction and maintenance of affective bonds, so praised in the care relationship, so it easily fits into nursing discourses. However, there are speeches in the academic environment that reinforce the belief that techniques overlap with empathy, devaluing the affective part of care. Caring is not only an affectionate way with the other, it 
is also reflective and rational. Thus, when referring to nursing care, there is no way to dissociate the affective part from the cognitive part, both complement each other. ${ }^{20}$

Some speeches of students and observations showed that the stimulus of empathy is directed only to the binomial student (future professional)-health services user, suggesting that there was no such care between teachers and students, which shows that there is a dissonance between what is said by teachers about nursing care and what is promoted in their relationship with students. Living consistently in accordance with your values is also part of value education. The challenge is to start teaching moral values by living them in the daily life of the school, working them from the micro (groups, classroom and/or educational institution) so that they can be incorporated into the macro environment (labor market and society).

It is noted that moral values are present in institutional discourses, as well as by their corridors, so it was questioned why working on empathy among the school members seemed more difficult than working with health users in practical activities, since, according to Hoffman, ${ }^{18}$ the empathic reaction occurs first with acquaintances and then with distant individuals. Therefore, theoretically it would be easier to empathize with students than with others who are outside the school environment, that is, outside the circle of conviviality.

For this question, three answers were obtained. The first is linked to the emerging vulnerability of patients, which empathizes more empathetically than with apparently healthy students in a classroom. The second is that teachers often have a detachment from students that does not allow them to know their emotions and anxieties and, consequently, produce feelings of empathy. And the third answer arose from the observations made, in which empathic relationships between teachers and patients were perceived; however, these same teachers had cold and apathetic relationships with students. It was assumed that the care relations between these teachers and the patients, permeated by empathy, are in the professional sphere, guiding the acting both technically and humanly, while the relations between the teachers and their students are within the care of In general, that expected among all individuals, regardless of profession, that is, there is no deontological standardization that requires him to maintain caring relationships, leaving the chance and the link of empathic posture to be associated with a personal inclination of the teacher.

The next discussion item aims to help (re)think the teaching practices, building care relationships beyond the professional scope.

\section{Educate to care for}

The title "educating to care" would suit discussions in diverse educational areas. Whereas we are interdependent beings ${ }^{21-22}$ and that we all need care, working on this practice as a social value would enhance the task of teaching to live, in all educational spheres, from elementary school to the university. When we converge this phrase into nursing, it almost sounds like a pleonasm. Nursing defines itself as the excellence of care, so educating to care could be the slogan from any of its schools.

Historically, nursing has systematized care for quality care. Thus, the other is the purpose of the profession, and looking at the other is present in the work routine. And how to teach caring for others?

It is well known that only classes loaded with theoretical content and that value technical skills do not guarantee the teaching and learning of care. Thus, different practices are added to the curriculum in order to teach caring taking care of others, whether in real or simulated environments, whether with sick people or not. And the question continues: do theoretical and practical classes guarantee the learning of care?

Apparently yes. In fact, we cannot deny the importance of the sum of these two teaching strategies, as long as they work in a meaningful way, that is, considering the student's previous knowledge, articulating the theoretical-practical knowledge and encouraging its protagonism. ${ }^{23}$ 
However, we can enhance the learning of care by promoting, as an institutional mission, the care of the students themselves (as well as the care of teachers and staff). That is, the school can, in addition to providing opportunities for the student to develop the skills and competences to care for each other, build spaces for both to take care of each other, involving the broad sense of care while biopsychosocial well-being.

The learning process of care is not linear. University students must continue to learn to receive care, work that is started by the family and schools because, learning to be cared for, they also learns how to care. As you take care of the others, you learn more about what care means. And as you learn to take care of yourself, the more you value the efforts of those who care for you. ${ }^{24}$

It seems redundant to emphasize the importance of care among students, as well as between teachers and staff, within the nursing undergraduate, after all the essence of that environment is care. But, in practice, this is not as obvious as it sounds. The statements presented about the promoted values suggest that teachers believe that prudence, respect, responsibility and empathy are among their teaching practices, values that make up care. At the same time, students report that these values are stimulated in the student-health user relationship, but they themselves do not feel cared for by these teachers in all situations of school life. In these circumstances, when the recipient does not recognize the care offered, we can admit that there has been failure to care. Therefore, care needs to be understood as a two-way street, and will only be effective in exchange when both caregiver and receiver are favored with the relationship, which implies recognition of moral interdependence. ${ }^{24}$

So, what would be the most meaningful and coherent way to teach care in a nursing degree? Taking care of the students, teachers and staff, living values such as prudence, respect, responsibility and empathy within interpersonal relationships and in daily school life. It is in the interpersonal relationships that education comes to fruition and the skills and abilities designed for students come to life. It is in this space for two that moral values are built. It is in the face-to-face encounter that the teacher establishes an enabling environment for the cognitive and moral development of the student. The teacher-student relationship is not neutral and, therefore, acquires relevance if understood as the smallest and most powerful space for working on value education. ${ }^{25}$

The teacher has a fundamental role in the moral formation of his students, but the teaching task supposes a work together to achieve the educational ends. This shared work, aligned with the institutional mission, is called moral culture. One way to advance the implementation of a moral culture at school is to provide spaces for reflection on the teaching practice itself. It is noteworthy that the teacher and the school can only facilitate the construction of moral personality, as this is a personal and non-transferable task. ${ }^{25}$

The question presented is valid to endorse the discussion about moral training in undergraduate nursing, helping in the reflection process of the school, so that it may come to rethink its practices and be able to plan activities consistent with the moral values in which it believes. Using the ethnography allowed us to experience situations that are not always explicit in the participants' statements, bringing more richness to the data analysis. However, as a limitation of this study, it is pointed out that the results cannot be generalized to the other schools, since they refer to the reality of a single institution.

\section{CONCLUSION}

The moral values that teachers and students consider important, as well as those they believe are promoted during graduation, converge to: prudence, respect, responsibility and empathy. And, fortunately, they not only characterize the profile of a good nurse, but also refer to the description of a good person.

However, regarding the moral values that the research participants consider to be promoted, there is a discrepancy. Students evaluate that moral values are stimulated when they relate to the 
student-user health relationship. However, they warn that they do not experience the same values within the student-teacher relationship, which generates a mismatch in the teaching and learning of care.

Therefore, it is argued that a powerful institutional strategy for teaching to care is to promote the care of students, teachers and staff themselves. For this, it is necessary to create living spaces in which moral values are present in a habitual, routine and natural way, being lived in the school daily life.

\section{REFERENCES}

1. Macintyre A. After virtue: a study in moral theory. 3rd ed. Indiana (US): University of Notre Dame Press; 2007.

2. Casado M, Martínez M, Neves MCP. eds. Declaration on ethics and integrity in university teaching. Barcelona (ES): University of Barcelona; 2018.

3. Finker M, Ramos FRS. The ethical dimension f Higher Education in Dentistry: a study in Brazil. Bordón [Internet]. 2017 [cited 2019 Aug 10]; 69(4):35-49. Available from:https://dx.doi.org/10.13042/ bordon.2017.690403

4. Finker M, Negreiros DP. Training $x$ education, Deontology $x$ ethics: rethinking concepts and repositioning professors. Rev ABENO [Internet]. 2018 [cited 2019 Apr 29];18(2):37-44. Available from: https://doi.org/10.30979/rev.abeno.v18i1.516

5. Brasil. Resolução CNE/CES n 3, 7 de novembro de 2001: Institui Diretrizes Curriculares Nacionais do Curso de Graduação em Enfermagem. Diário Oficial da União, Brasília, DF(BR), 7 set. 2001. Available from: http://portal.mec.gov.br/cne/arquivos/pdf/ces03.pdf

6. Puig JM. La construcción de la personalidad moral. Barcelona (ES): Paidós; 1996.

7. Geertz C. Uma descrição densa: por uma teoria interpretativa da cultura. In: Geertz C. A interpretação das culturas. Rio de Janeiro, RJ(BR): LTC Editora; 1989. p.13-41.

8. Minayo MCS. Fase de análise do material qualitativo. In: Minayo MCS, editor. O desafio do conhecimento: pesquisa qualitativa em saúde. Rio de Janeiro, RJ(BR): HUCITEC; 2014. p. 303-60.

9. Piaget J. La relación del afecto con la inteligencia en el desarrollo mental del niño. In: Delahanty G, Perrés J, editors. Piaget y el psicoanálisis. Xochimilco (MX): Universidad Autónoma Metropolitana; 1994. p. 181-289.

10. Arantes VA. Educação e valores. 2nd ed. São Paulo, SP(BR): Summus Editorial; 2007.

11. Aristóteles. Ética a Nicômaco. 4th ed. São Paulo, SP(BR): Edipro; 2014.

12. Spitz V. Doctors from hell. Boulder (US): Sentient Publications; 2005.

13. Roedel CC. As virtudes intelectuais em Sto. Tomás de Aquino. Anais do III Congresso de Pesquisa e Extensão da Faculdade da Serra Gaúcha [Internet]. 2015 Sept 15-17 [cited 2019 Feb 10]: 308-18. Available from: http://ojs.fsg.br/index.php/pesquisaextensao/article/view/1564

14. Lima MM, Reibnitz KS, Kloh D, Silva KL, Ferraz F. The pedagogical relationship in practicalreflexive education: characteristic elements of teaching integrality in nurse education. Texto Contexto Enferm [Internet]. 2018 [cited 2019 Mar 11];27(2):1-10. Available from: https://dx.doi. org/10.1590/0104-070720180001810016

15. Sennett R. El respeto. Sobre la dignidad del hombre en un mundo de desigualdad. Barcelona (ES): Editorial Anagrama; 2003.

16. Kant I. Fundamentação da metafísica dos costumes. Lisboa (PT): Edições 70; 2005.

17. Neves Júnior WA, Araújo LZS, Rego S. The teaching of bioethics in medical schools in Brazil. Rev Bioét [Internet]. 2016 [cited 2019 Jan 20];24(1):98-107. Available from: https://dx.doi. org/10.1590/1983-80422016241111 
18. Hoffman ML. Desarrollo moral y empatía. Barcelona (ES): Idea Books; 2002.

19. Jami PY, Mansouri B, Thoma SJ, Han H. An investigation of the divergences and convergences of trait empathy across two cultures. J Moral Educ [Internet]. 2019 [cited 2019 Aug 10];48(2):21429. Available from: https://dx.doi.org/10.1080/03057240.2018.1482531

20. Mayano LG. La ética del cuidado y su implicación en la profesión enfermera. Acta Bioethica [Internet]. 2015 [cited 2019 Jan 20];21(2):311-7. Available from: https://dx.doi.org/10.4067/ S1726-569X2015000200017

21. Puig JM, Martínez M. Educación moral y democracia. Barcelona (ES): Laertes; 1989.

22. Cortina A. Ética mínima: introducción a la filosofía práctica. Madrid (ES): Tecnos; 2009.

23. Marques LMNS. Active methodologies as strategies to develop education in values in nursing graduation. Esc Anna Nery Rev Enferm [Internet]. 2018 [cited 2019 Jan 20]; 22(3):1-6. Available from: https://dx.doi.org/10.1590/2177-9465-ean-2018-0023.

24. Noddings N. La educación moral: propuesta alternativa para la educación del carácter. Buenos Aires (AR): Amorrortu; 2009.

25. Martínez M, Esteban F, Gonzalo J, Payà M. Con buenas intenciones solo, no basta. In: Martínez M, Esteban F, Gonzalo J, Payà M. La educación, en teoría. Madrid (ES): Editorial Síntesis; 2016. p. 47-67. 


\section{NOTES}

\section{ORIGIN OF THE ARTICLE}

Extracted from the thesis - Moral training in nursing undergraduation presented to the Graduate Program in Bioethics, Applied Ethics and Collective Health of the associated institutions: Universidade Federal Fluminense, Universidade Federal do Rio de Janeiro, Universidade Estadual do Rio de Janeiro e Fundação Oswaldo Cruz (FIOCRUZ), in 2019.

\section{CONTRIBUTION OF AUTHORITY}

Study desing: Marques LMNS; Ribeiro CD.

Data collection: Marques LMNS.

Analysis and interpretation of data: Marques LMNS.

Discussion of the results: Marques LMNS.

Writing and/or critical review of content: Marques LMNS; Ribeiro CD.

Review and final approval of the final version: Marques LMNS; Ribeiro CD.

\section{ACKNOWLEDGMENT}

To Xus Martín Garcia and the other teachers of the Research Group on Moral Education (Grup de Recerca en Educació Moral, GREM) at the University of Barcelona for taking the time to make pertinent suggestions during the writing of this article.

\section{FINANCING}

CAPES Fellow/Sandwich Doctorate Program Abroad/Process No. 88881.189647/2018-01.

\section{APPROVAL OF ETHICS COMMITTEE IN RESEARCH}

Approved by the Research Ethics Committee of Escola de Enfermagem Anna Nery, Opinion No.2,469,585/2019. Certificate of Presentation for Ethical Appreciation (Certificado de Apresentação para Apreciação Ética, CAAE) 73677917.7.3001.5238.

\section{CONFLICT OF INTERESTS}

There is no conflict of interest.

\section{HISTORY}

Received: April 30, 2019.

Approved: August 29, 2019.

\section{CORRESPONDING AUTHOR}

Lumaira Maria Nascimento Silva da Rocha Marques

lumaira_@hotmail.com 